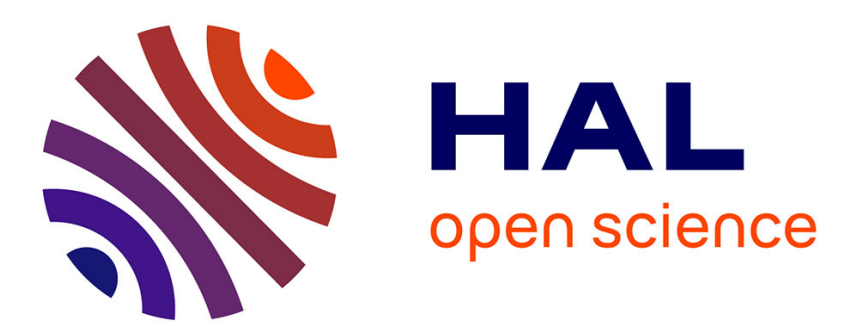

\title{
Reduction of uranium oxide U3O8 into uranium dioxide UO2 by ammonia
}

\author{
Françoise Valdivieso, Michèle Pijolat, Michel Soustelle, J. Jourde
}

\section{To cite this version:}

Françoise Valdivieso, Michèle Pijolat, Michel Soustelle, J. Jourde. Reduction of uranium oxide U3O8 into uranium dioxide UO2 by ammonia. XIVth International Symposium on the Reactivity of Solids., Aug 2000, Budapest, Hungary. pp.117-122, 10.1016/S0167-2738(01)00730-5 . hal-00409697

\section{HAL Id: hal-00409697 https://hal.science/hal-00409697}

Submitted on 12 Aug 2009

HAL is a multi-disciplinary open access archive for the deposit and dissemination of scientific research documents, whether they are published or not. The documents may come from teaching and research institutions in France or abroad, or from public or private research centers.
L'archive ouverte pluridisciplinaire HAL, est destinée au dépôt et à la diffusion de documents scientifiques de niveau recherche, publiés ou non, émanant des établissements d'enseignement et de recherche français ou étrangers, des laboratoires publics ou privés. 


\title{
Reduction of uranium oxide $\mathrm{U}_{3} \mathrm{O}_{8}$ into uranium dioxide $\mathrm{UO}_{2}$ by ammonia
}

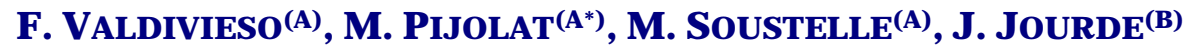 \\ (A) Laboratoire des Procédés en Milieux Granulaires CNRS UMR 5148, Centre SPIN, Ecole \\ Nationale Supérieure des Mines, 158 Cours Fauriel, 42023 Saint-Etienne Cedex 2, \\ France \\ (B) COMURHEX, Usine de Malvési, BP222, 11102 Narbonne, France
}

\section{(*) mpijolat@emse.fr}

Key words:

uranium oxide ; reduction ; ammonia ; decomposition ; hydrogen

\begin{abstract}
The reduction of uranium oxide $\mathrm{U}_{3} \mathrm{O}_{8}$ into uranium dioxide $\mathrm{UO}_{2}$ has been studied by temperature programmed thermogravimetry, up to $700^{\circ} \mathrm{C}$. Experiments have been carried out either in ammonia $\left(\mathrm{P}_{\mathrm{NH} 3}\right.$ ranging from 35 to $125 \mathrm{hPa}$ ) or hydrogen ( $\mathrm{P}_{\mathrm{H} 2}$ ranging from 42 to $243 \mathrm{hPa}$ ). The gases evolved and consumed during the reduction were followed

simultaneously by mass spectrometry. The reduction of $\mathrm{U}_{3} \mathrm{O}_{8}$ by ammonia into $\mathrm{UO}_{2}$ begins at $550^{\circ} \mathrm{C}$, and is completed at about $650^{\circ} \mathrm{C}$. It has been noticed that ammonia decomposition occurs at $700^{\circ} \mathrm{C}$; moreover, it is catalysed by $\mathrm{UO}_{2}$ produced by the reduction of $\mathrm{U}_{3} \mathrm{O}_{3}$, since no decomposition is observed in the absence of $\mathrm{UO}_{2}$. Besides, some isothermal experiments carried out at $510^{\circ} \mathrm{C}$ have confirmed that ammonia reacts directly with $\mathrm{U}_{3} \mathrm{O}_{8}$, since the shape of the curves obtained either in ammonia or in hydrogen are different: particularly, the reaction is faster with ammonia compared to hydrogen, for the same partial pressure of the reducing gas.
\end{abstract}

\section{Introduction}

The reduction of uranium oxide $\mathrm{U}_{3} \mathrm{O}_{8}$ to uranium dioxide $\mathrm{UO}_{2}$ has been studied by temperature programmed thermogravimetry, up to $700^{\circ} \mathrm{C}$, the experiments being carried out either in ammonia or hydrogen. The reduction of $\mathrm{U}_{3} \mathrm{O}_{8}$ by hydrogen has already been studied [1], and a comprehensive modelling of the transformation has been proposed. The comparison between ammonia and hydrogen was done in order to verify if ammonia reacts directly with $\mathrm{U}_{3} \mathrm{O}_{8}$, or if the reducing gas is hydrogen produced by the decomposition of ammonia, as suggested in the literature [2].

\section{Experimental}

The $\mathrm{U}_{3} \mathrm{O}_{8}$ powder was obtained by calcining in air at $700^{\circ} \mathrm{C}$ during two hours a $\mathrm{UO}_{3}$ powder, supplied by Comurhex. It has been verified by X-Ray diffraction that the calcinated powder is composed of $\mathrm{U}_{3} \mathrm{O}_{8}$, the peaks corresponding to $\mathrm{UO}_{3}$ having disappeared. The BET surface area of the $\mathrm{U}_{3} \mathrm{O}_{8}$ powder is $3 \mathrm{~m}^{2} \cdot \mathrm{g}^{-1}$ (determined using $\mathrm{Kr}$ adsorption at $77 \mathrm{~K}$, with a Micromeritics Asap 2000).

The thermogravimetry experiments have been carried out in a TAG24 Setaram thermobalance, at atmospheric pressure, under a flowing gas (total flowrate : $41 . h^{-1}$ ) in which the partial pressures of the gases were controlled by flowmeters (the carrier gas being helium). Experiments have been carried out either in ammonia ( $\mathrm{P}_{\mathrm{NH} 3}$ ranging from 35 to $125 \mathrm{hPa}$ ) or hydrogen $\left(\mathrm{P}_{\mathrm{H} 2}\right.$ ranging from 42 to $\left.243 \mathrm{hPa}\right)$. The initial mass of the samples was about 35mg.

The gases evolved and consumed during the reduction were followed simultaneously by mass spectrometry (BALZERS QMG 420C). 
The X-ray diffraction experiments have been carried out using a diffractometer Siemens $\mathrm{D} 5000(\mathrm{Cu} \mathrm{K \alpha})$. In order to determine precisely the position of the diffraction peaks in the $\mathrm{UO}_{2}$ samples, $\alpha$-alumina powder was added to the $\mathrm{UO}_{2}$ powder as an internal standard.

\section{Experimental results}

\section{1- Reduction of $\mathrm{U}_{3} \mathrm{O}_{8}$ by ammonia}

A sample of $\mathrm{U}_{3} \mathrm{O}_{8}$ has been heated up to $700^{\circ} \mathrm{C}\left(10^{\circ} \mathrm{C} / \mathrm{min}\right)$ under a flowing mixture of helium and ammonia $\left(\mathrm{P}_{\mathrm{NH} 3}=125 \mathrm{hPa}\right)$; it was maintained at $700^{\circ} \mathrm{C}$ during 10 minutes, before being

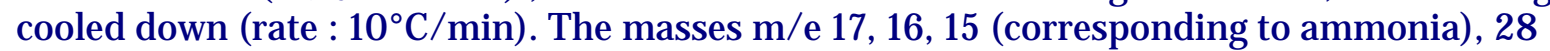
(nitrogen), 18 (water vapour), and 2 (hydrogen) were followed by mass spectrometry during the whole experiment. The curve of weight loss and the evolution of the various gases versus time are shown in figure 1 (the curve corresponding to the mass $\mathrm{m} / \mathrm{e}=15$, characteristic of ammonia only, is not represented here, since the chosen scale is not appropriate (this signal is nearly 100 times lower than the signal corresponding to $\mathrm{m} / \mathrm{e}=16$ ), but its evolution is exactly the same as the evolution of the masses 16 and 17).

The total weight loss is $3.7 \%$ (figure $1 \mathrm{a}$ ), which is slightly lower than the theoretical weight loss corresponding to the reduction of $\mathrm{U}_{3} \mathrm{O}_{8}$ into $\mathrm{UO}_{2}$ (3.82\%).

It can be noticed that simultaneously to the weight loss linked to the reduction (which begins at about $550^{\circ} \mathrm{C}$ ), ammonia is consumed and nitrogen and water vapour are released (figures $\mathrm{lb}$ and $1 \mathrm{c})$. When the reaction is completed, at about $650^{\circ} \mathrm{C}$, the various gases come back to their initial level ; then, during the isothermal step $\left(10\right.$ minutes at $\left.700^{\circ} \mathrm{C}\right)$, the decomposition of ammonia is observed (decreasing signal for $\mathrm{NH}_{3}(16,17)$ and increasing for $\mathrm{N}_{2}(28)$ and $\mathrm{H}_{2}$ (2)). However, there is no evolving of water (18), which is in agreement with the decomposition reaction. During the cooling of the sample, all signals come back to their initial level, the decomposition of ammonia stops as soon as the temperature decreases ; no weight loss neither gaseous evolving are observed during the cooling.

This experiment shows that ammonia reacts directly with $\mathrm{U}_{3} \mathrm{O}_{8}$, the decomposition is observed only at $700^{\circ} \mathrm{C}$, when the sample is completely reduced into $\mathrm{UO}_{2}$. In order to verify that the decomposition is not linked to the reaction of reduction, this sample of $\mathrm{UO}_{2}$, cooled under ammonia, has been heated up again to $700^{\circ} \mathrm{C}$, under the same gaseous atmosphere (ammonia and helium) : the results are indicated in figure 2. The decomposition of ammonia is observed as soon as the temperature reaches $700^{\circ} \mathrm{C}$ and during the isothermal step (30 minutes), but it no longer occurs when the temperature decreases. Moreover, a similar experiment carried out in the same conditions of temperature and pressure, but without any sample, has shown that the decomposition of ammonia does not occur (which is in agreement with the literature data $[3,4]$, since at this temperature the decomposition is observed only in the presence of metallic catalysts).

From these experiments, it can be concluded that ammonia decomposition is not due to the reaction of reduction, and that uranium dioxide $\mathrm{UO}_{2}$ is a catalyst for this decomposition.

\section{2- Comparison between the reduction curves in ammonia and hydrogen}

In order to compare the effect of ammonia and hydrogen, an experiment has been carried out up to $700^{\circ} \mathrm{C}\left(10^{\circ} \mathrm{C} / \mathrm{min}\right)$ under flowing helium and hydrogen $\left(\mathrm{P}_{\mathrm{H} 2}=85 \mathrm{hPa}\right)$. Figure 3 shows the curves of weight loss and rate of weight loss obtained under ammonia ( $125 \mathrm{hPa}$ ) and hydrogen $(85 \mathrm{hPa}): \mathrm{U}_{3} \mathrm{O}_{8}$ reduction occurs in the same temperature range and with a similar rate for the two gases, the weight loss obtained under hydrogen being slightly higher (3.89\% instead of 3.7\%).

Some isothermal experiments have also been carried out, at $510^{\circ} \mathrm{C}$, the reducing gas being introduced in the thermobalance when the temperature is stabilised (as shown by the arrow in figure 4).

Figure 4 shows a curve obtained at $510^{\circ} \mathrm{C}$ under $125 \mathrm{hPa}$ of ammonia : a rapid weight loss is observed firstly, then the rate decreases, passes through a maximum and decreases again. The final weight loss is $3.41 \%$, which is lower than the theoretical weight loss. However, the 
reaction seems to be completed, since the sample mass remains constant after 40 minutes at $510^{\circ} \mathrm{C}$. XRD experiments have shown that both $\mathrm{U}_{3} \mathrm{O}_{8}$ and $\mathrm{UO}_{2}$ are observed in a sample cooled after the first weight loss $(\Delta \mathrm{m}=0.5 \%)$, and that a sample analysed at the end of the reaction exhibits only the $\mathrm{UO}_{2}$ peaks.

The effect of the partial pressure of ammonia is illustrated in figure 5, which shows the curves obtained under $125 \mathrm{hPa}$ and $42.5 \mathrm{hPa}$ : an accelerating effect of ammonia is observed after the first weight loss.

A comparison of the curves obtained under ammonia and hydrogen, with the same partial pressure $(42.5 \mathrm{hPa})$, is given in figure $6 a$, the curves representing the rate $\mathrm{d}(\Delta \mathrm{m}) / \mathrm{dt}$ versus the weight loss are represented in figure $6 \mathrm{~b}$. It can be noticed that the reduction is faster in ammonia, but that the total weight loss obtained in hydrogen is higher (3.8\%), in agreement with the theoretical weight loss.

Despite the fact that the shape of the curves is quite different, it can be observed, in both cases, a first maximum of the rate (for a weight loss lower than about $0.6 \%$ ), then a second maximum, the inflexion point being situated at about $\Delta \mathrm{m}=2.3 \%$ for ammonia and $0.7 \%$ for hydrogen.

In order to explain the difference in the final weight loss for samples reduced under ammonia $(\approx 3.4 \%)$ or hydrogen $(\approx 3.8 \%)$, XRD experiments have been performed on the two samples resulting from the experiments shown in figure 6 . If we assume that the uranium dioxide obtained under ammonia is a non-stoichiometric $\mathrm{UO}_{2+\mathrm{x}}$ oxide, the experimental weight loss (3.41\%) would correspond to a value of $\mathrm{x}$ equal to 0.07 and the diffraction peaks should be shifted towards higher angles.The positions corresponding to $\mathrm{UO}_{2,07}$ can be calculated knowing the cell parameter « $\mathrm{a}$ » for $\mathrm{UO}_{2}\left(\mathrm{a}=5.467 \AA\right.$, J CPDS file 41-1422) and $\mathrm{UO}_{2.25}(\mathrm{a}=5.441$ $\AA$, J CPDS file 20-1344). Assuming that a is a linear function of $x$ (Vegard's law), the cell parameter a for $\mathrm{UO}_{2.07}$ would be equal to $5.459 \AA$. Then, the $\mathrm{d}_{\mathrm{hkl}}$ distances and the corresponding angles can be evaluated, they are reported in table 1.

Figures $7 \mathrm{a}$ and $7 \mathrm{~b}$ show the diffractograms obtained for the two samples reduced under ammonia or hydrogen, the positions of the peaks for $\mathrm{UO}_{2}$ and $\mathrm{UO}_{2.07}$ being indicated (some peaks corresponding to $\alpha$-alumina used as a standard are observed too). The experimental values of the peak positions are reported in the two last columns of table 1 for both samples. The expected shift between $\mathrm{UO}_{2}$ and $\mathrm{UO}_{2.07}$ being small, it may be quite difficult to detect experimentally. Nevertheless, considering the peaks magnified in figures $7 \mathrm{a}$ and $7 \mathrm{~b}$ and the values given in table 1, it can be concluded that the peaks corresponding to the sample reduced under ammonia are not significantly shifted compared to those of the sample reduced in hydrogen and do not correspond to $\mathrm{UO}_{2.07}$. Thus, it seems that the experimental weight loss obtained in ammonia can not be accounted for by the formation of a non stoichiometric $\mathrm{UO}_{2+\mathrm{x}}$.

This weight loss could also have been due to ammonia adsorption at the surface of the $\mathrm{UO}_{2}$ oxide, but none of the bands characteristic of ammonia have been detected by infra-red spectroscopy experiments.

Further investigations are being performed in order to explain this experimental weight loss, and the shape of the kinetic curves.

\section{Conclusions}

The reduction of $\mathrm{U}_{3} \mathrm{O}_{8}$ by ammonia has been studied by thermogravimetry and mass spectrometry. It has been shown that $\mathrm{U}_{3} \mathrm{O}_{8}$ is reduced directly by ammonia, which is not decomposed during the reduction process. Ammonia decomposition occurs in our experimental conditions at about $700^{\circ} \mathrm{C}$, only in the presence of uranium dioxide $\mathrm{UO}_{2}$, which acts as a catalyst (no decomposition is observed without $\mathrm{UO}_{2}$ ).

Isothermal experiments at $510^{\circ} \mathrm{C}$ have confirmed that ammonia reacts directly with $\mathrm{U}_{3} \mathrm{O}_{8}$, since the shape of the curves obtained either in ammonia or in hydrogen are different ; 
besides, the reaction is faster with ammonia compared to hydrogen, for the same partial pressure of the reducing gas.

Finally, it has been noticed that the final weight loss obtained in ammonia (about 3.4\%) is always lower than the theoretical one (3.82\%). XRD experiments seem to show that this result cannot be accounted for by the formation of a non stoichiometric uranium dioxide $\mathrm{UO}_{2+x}$ $\left(\mathrm{UO}_{2.07}\right)$. Further investigation are necessary to elucidate this point.

\section{References}

[1] C. Brun, M. Pijolat, F. Valdivieso, M. Soustelle, Phys. Chem. Chem. Phys. 1 (1999) 471.

[2] I.A. El-Shanshoury, A.F. Bishay, Arab Republic of Egypt Atomic Energy Establishment, A.R.E.A.E.E., Rep. 139 (1972).

[3] J.B. Hansen, Nielsen (Ed.), Ammonia, Springer-Verlag Berlin Heidelberg (1995) 150.

[4] M. Grunze, Chemical Physics of Solid Surfaces and Heterogeneous catalysis, D.A. King (Ed.) 4 (1982) 143.

\section{FIGURE CAPTIONS}

Figure 1: Heating of $\mathrm{U}_{3} \mathrm{O}_{8}$ under ammonia $\left(700^{\circ} \mathrm{C}, 10^{\circ} \mathrm{C} / \mathrm{min}, \mathrm{P}_{\mathrm{NH} 3}=125 \mathrm{hPa}\right)$; weight loss curve (a) and evolved gas (b-c).

Figure 2: Evolved gas during the heating $\left(700^{\circ} \mathrm{C}, 10^{\circ} \mathrm{C} / \mathrm{min}\right)$ and the cooling of $\mathrm{UO}_{2}$ in ammonia $\left(\mathrm{P}_{\mathrm{NH} 3}=125 \mathrm{hPa}\right)$.

Figure 3: Heating of $\mathrm{U}_{3} \mathrm{O}_{8}\left(700^{\circ} \mathrm{C}, 10^{\circ} \mathrm{C} / \mathrm{min}\right)$ under ammonia $\left(\mathrm{P}_{\mathrm{NH} 3}=125 \mathrm{hPa}\right)$ or hydrogen $\left(\mathrm{P}_{\mathrm{H} 2}=85 \mathrm{hPa}\right)$; curves of weight loss and rate of weight loss.

Figure 4: Curves of weight loss and rate of weight loss versus time in isothermal conditions $\left(\mathrm{T}=510^{\circ} \mathrm{C}\right)$, in ammonia $\left(\mathrm{P}_{\mathrm{NH} 3}=125 \mathrm{hPa}\right)$.

Figure 5: Effect of the ammonia partial pressure on the reduction of $\mathrm{U}_{3} \mathrm{O}_{8}$ at $510^{\circ} \mathrm{C}$.

Figure 6: Comparison of the curves obtained in ammonia ( $42.5 \mathrm{hPa})$ or hydrogen $(42.5 \mathrm{hPa})$; weight loss versus time (a) and rate of weight loss versus weight loss (b).

Figure 7: Diffractograms of uranium dioxide samples obtained from the reduction of $\mathrm{U}_{3} \mathrm{O}_{8}$ by ammonia or hydrogen ; $2 \theta$ angle ranging from 27 to 34 (a), and 46 to 60 (b).

\section{TABLE CAPTION}

Table 1: Positions of the diffraction peaks for $\mathrm{UO}_{2}$ (J CPDS file 41-1422) and $\mathrm{UO}_{2.07}$ (calculated) and positions of the experimental diffraction peaks observed in the samples reduced under hydrogen or ammonia.

\begin{tabular}{|ccccccc}
\hline & \multicolumn{2}{c}{$\mathrm{UO}_{2}$} & \multicolumn{2}{c}{$\mathrm{UO}_{2.07}$} & $\begin{array}{c}\text { Experimental } \\
\left(\mathrm{H}_{2}\right)\end{array}$ & $\begin{array}{c}\text { Experimental } \\
\left(\mathrm{NH}_{3}\right)\end{array}$ \\
\hline$[\mathrm{hkl}]$ & $\mathrm{d}_{\text {hkl }}(\AA)$ & $2 \theta$ & $\mathrm{d}_{\text {hkl }}(\AA)$ & $2 \theta$ & $2 \theta$ & $2 \theta$ \\
\hline$[111]$ & 3.153 & 28.28 & 3.152 & 28.29 & 28.26 & 28.27 \\
\hline$[200]$ & 2.733 & 32.74 & 2.729 & 32.78 & 32.74 & 32.74 \\
\hline$[220]$ & 1.933 & 46.97 & 1.930 & 47.04 & 46.97 & 46.99 \\
\hline$[311]$ & 1.647 & 55.75 & 1.646 & 55.81 & 55.72 & 55.74 \\
\hline$[222]$ & 1.578 & 58.43 & 1.576 & 58.52 & 58.43 & 58.47 \\
\hline
\end{tabular}


FV-14th IRS Budapest-2000
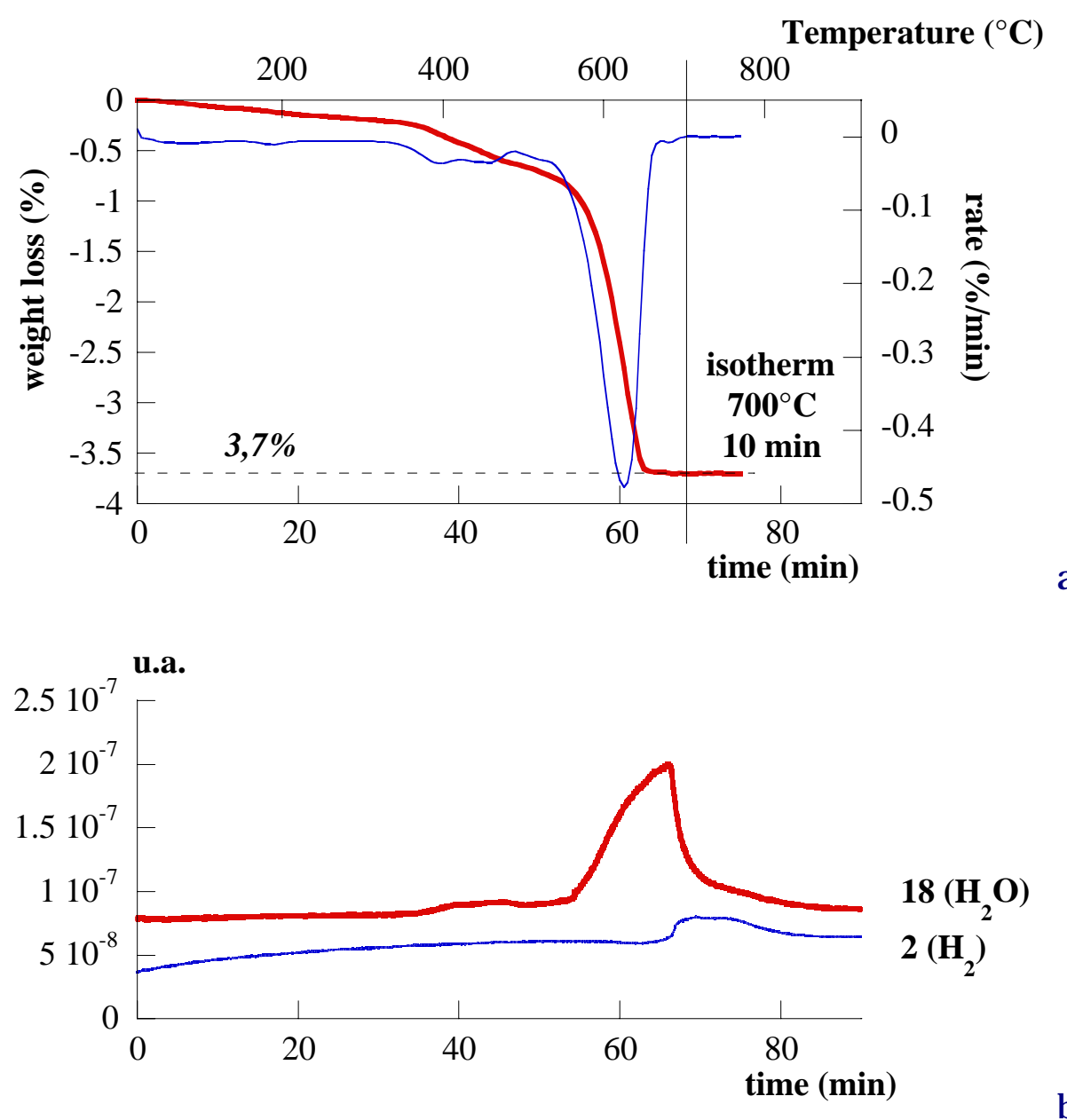

$\mathrm{b}$

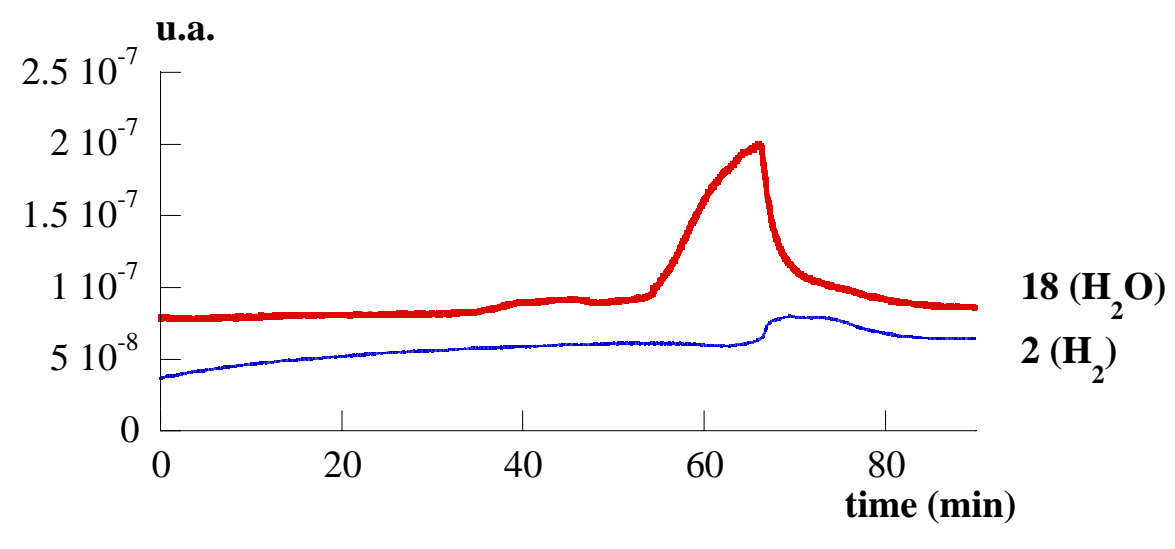

Figure 1: 
FV-14th IRS Budapest-2000

u.a.

Temperature $\left({ }^{\circ} \mathrm{C}\right)$

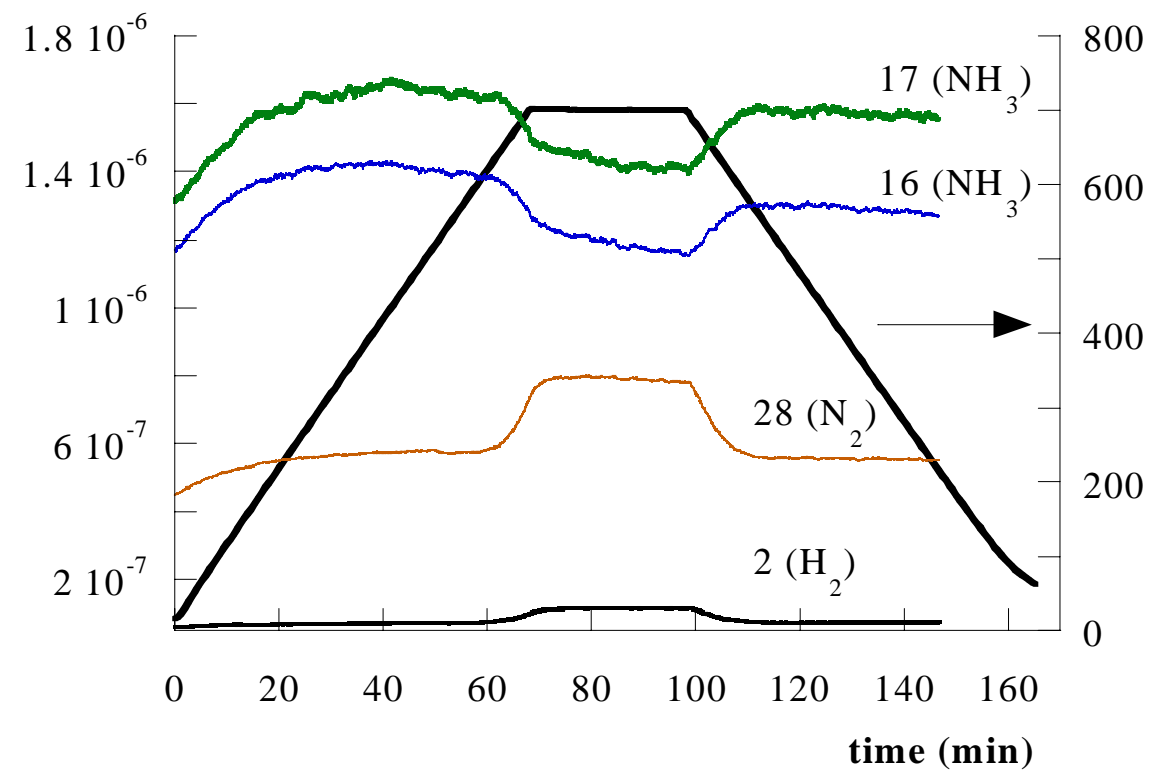

Figure 2:

Weight loss (\%) Rate $(\% / \mathrm{min})$

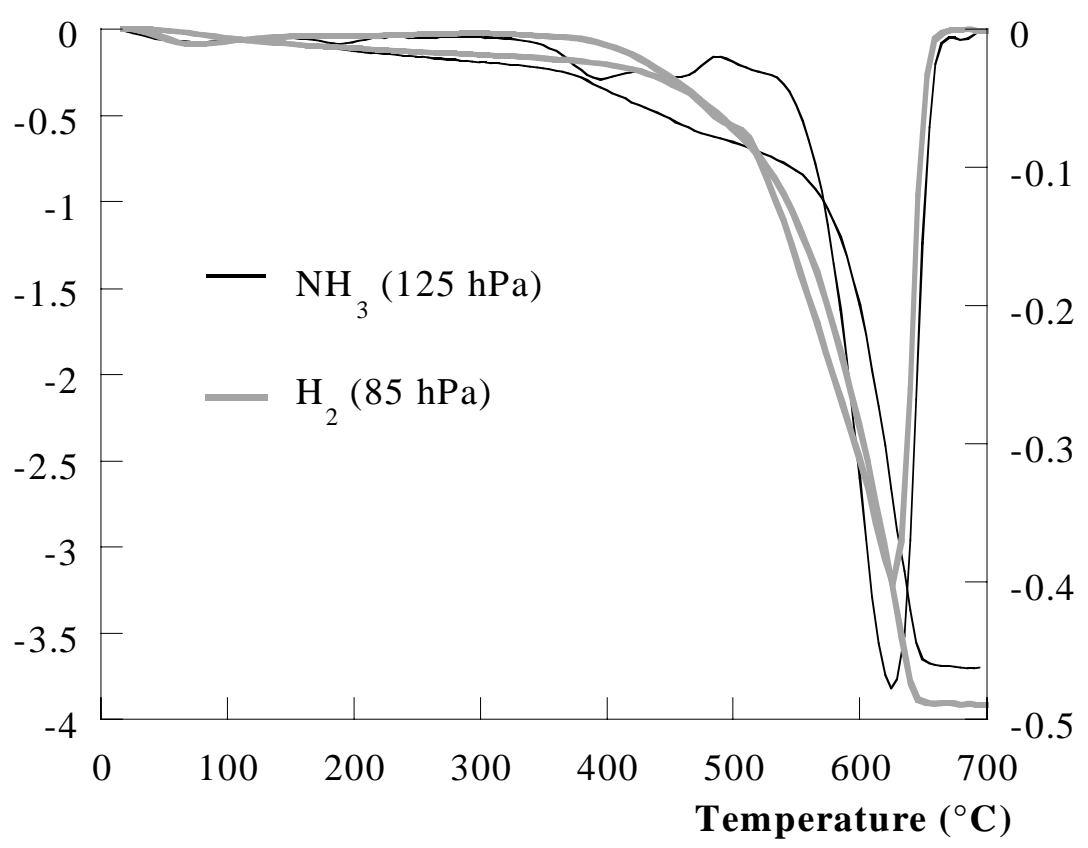

Figure 3: 
FV-14th IRS Budapest-2000

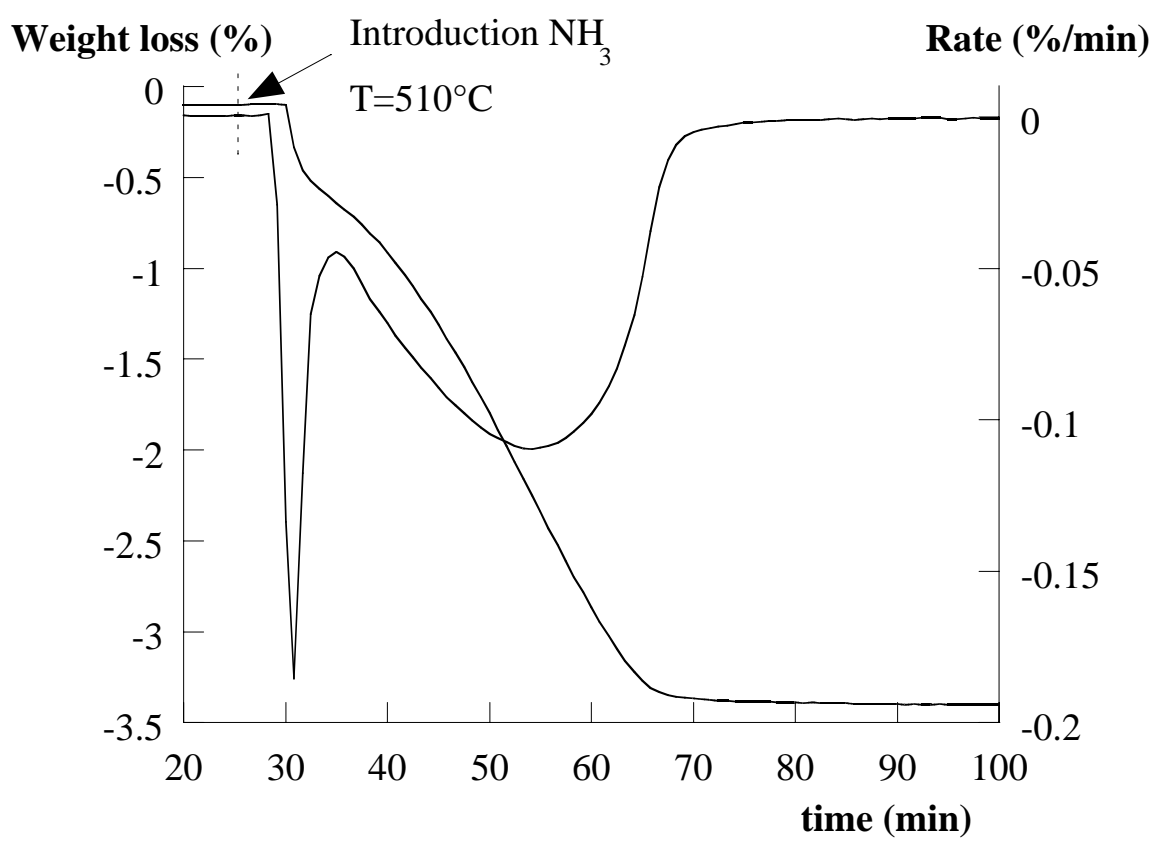

Figure 4:

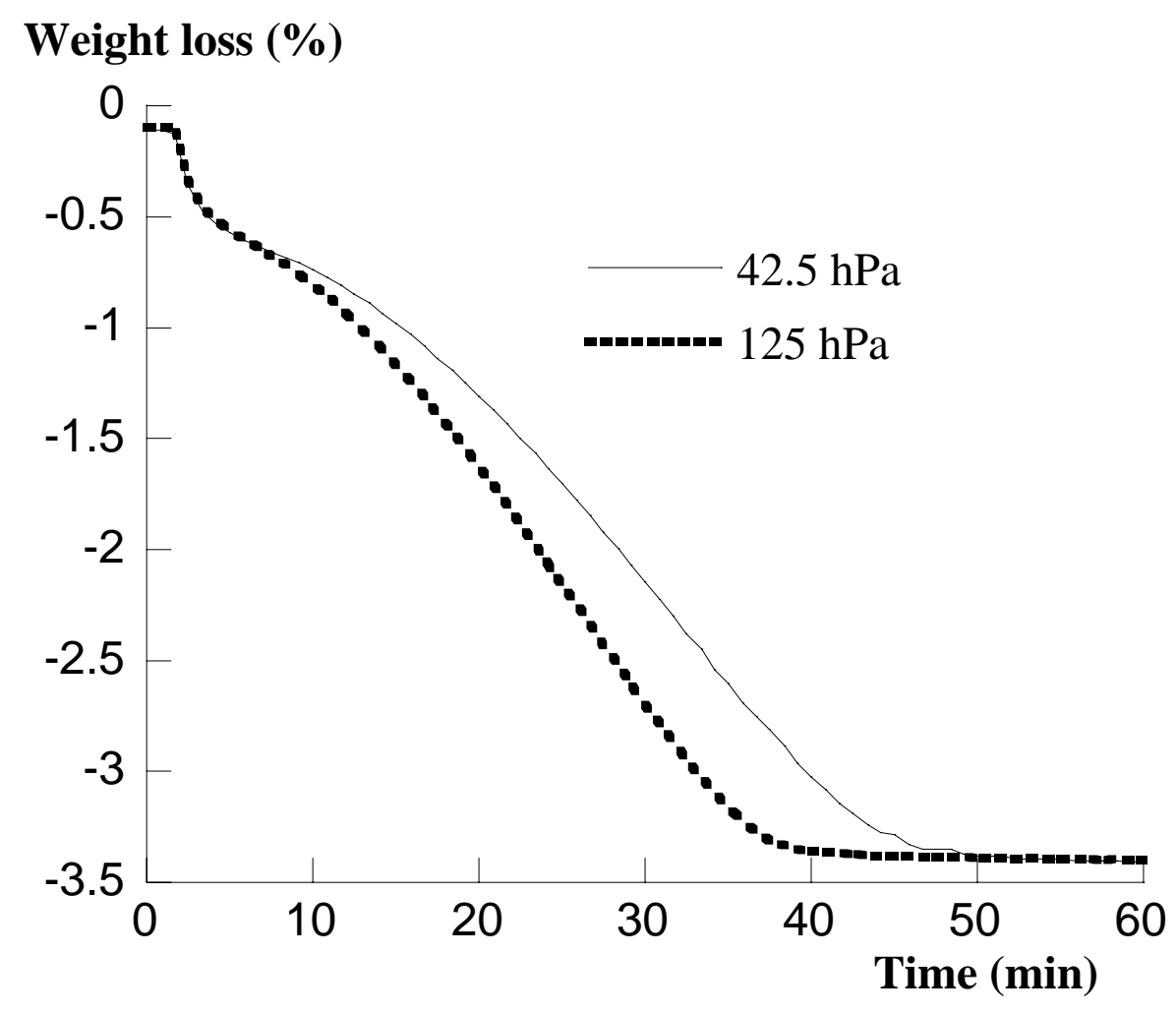

Figure 5: 
FV-14 ${ }^{\text {th }}$ IRS Budapest-2000

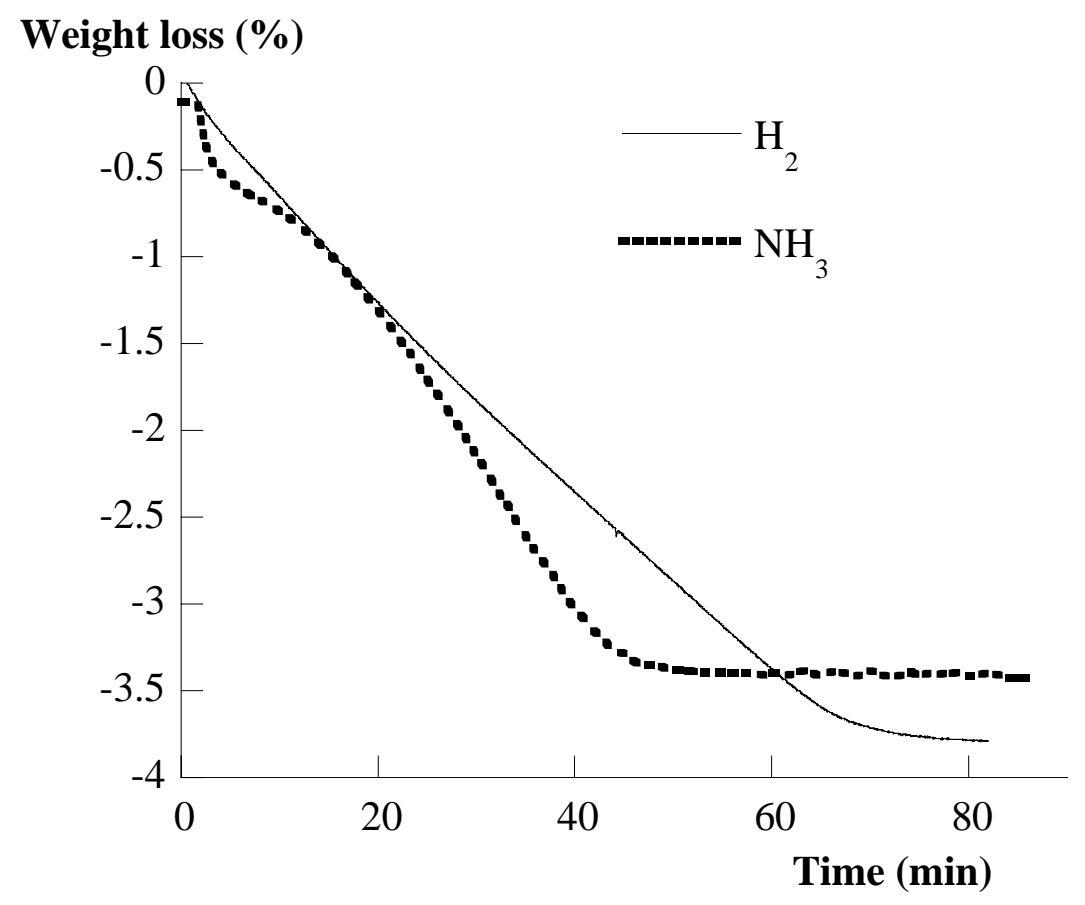

Rate (\%/min)

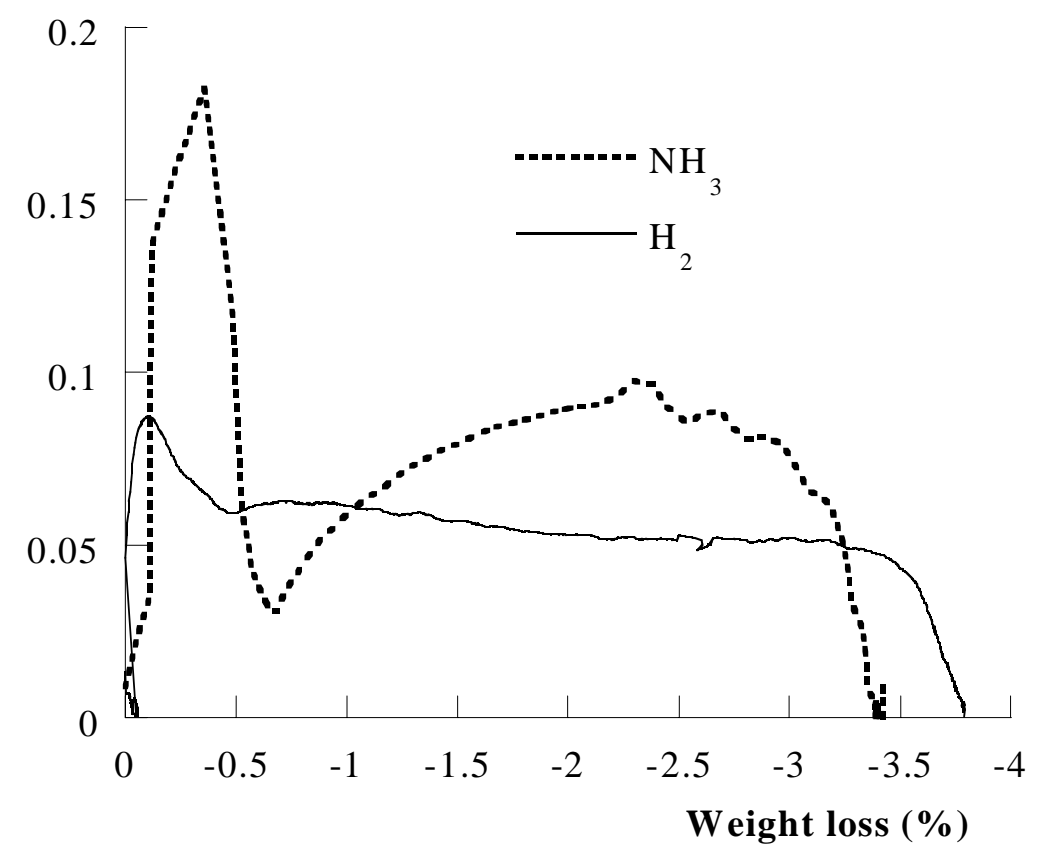

Figure 6: 

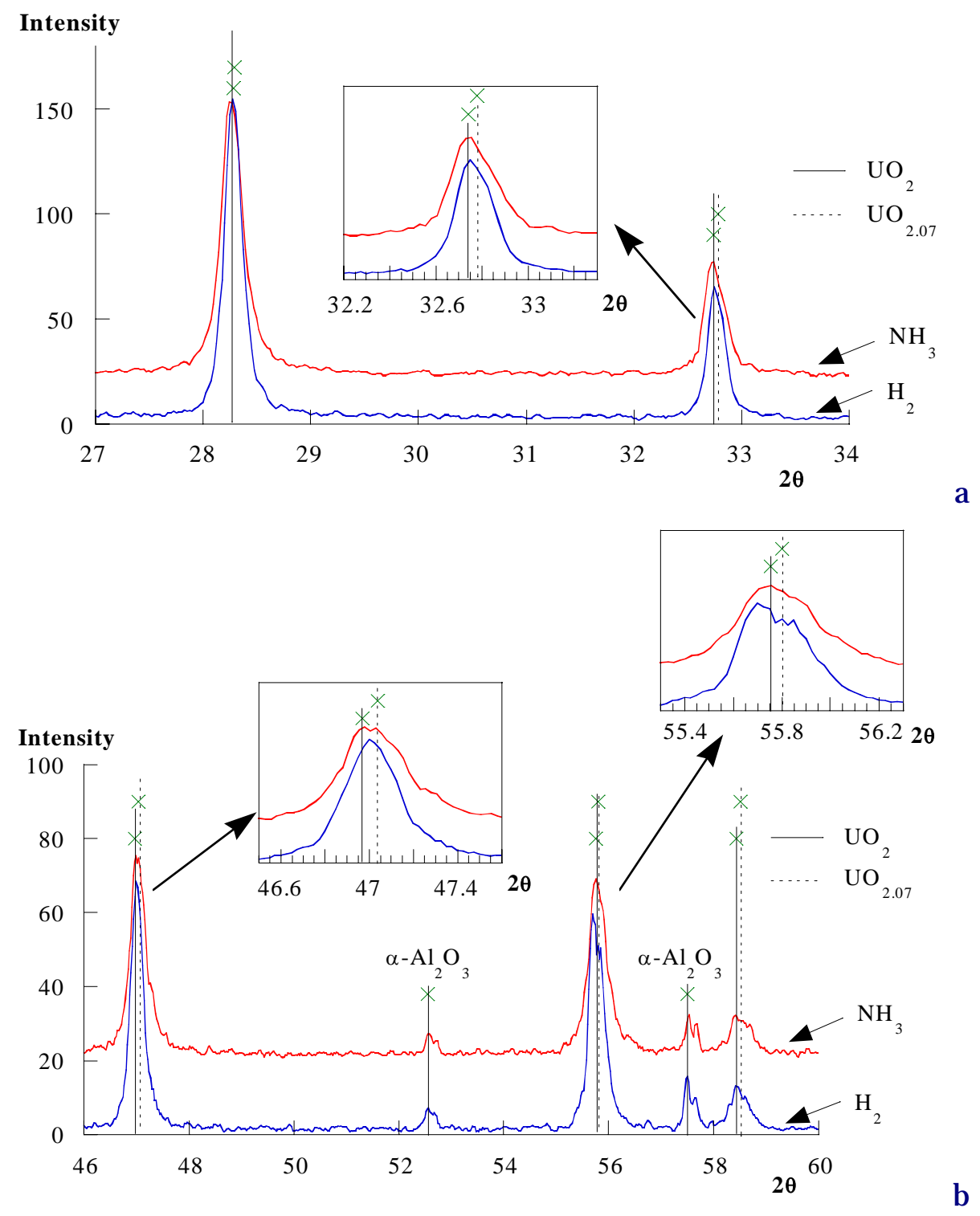

Figure 7: 